\title{
Life-Style Reflections On The Architecture Of The Single-Family House In Erbil City Based On The Income
}

\section{Hadar Ihsan Ali}

Department of interior design, College of engineering, Tishk and Salahddin University, Erbil, Kurdistan Region, Iraq

Hadaralkraidi@yahoo.com

\section{Mahmod Ahmad Alkayat}

Department Of Architecture, College Of Engineering, Salahddin and UKH University, Erbil, Kurdistan Region, Iraq dr.m.khayat@gmail.com

\section{ARTICLE INFO}

\section{Article History:}

Received: 23/4/2020

Accepted: 19/5/2020

Published: Spring2020

\section{Keywords:}

Lifestyle; Interior

Architecture; dwelling unit's components, Erbil City-Kurdistan of Iraq.

Doi:

\begin{abstract}
The study aims to determine an existing pattern of living (lifestyle) in Erbil city and its reflection on architecture and dwelling unit components. A case study methodology has been approached, and 30 residential buildings have been selected to be analyzed in Erbil as the limit of the study. The buildings have been divided into three categories (Low, Mid, and High) based on the income of the families in the region of study. The observation and questionnaire methods have been conducted to reach the results. The observation factors were developed and have been applied to determine lifestyle patterns in Erbil city. A questionnaire has been developed to identify lifestyle patterns by asking people about their daily life patterns and how it was reflected in the architecture
\end{abstract}


10.25212/Ifu.qzj.5.2.33 design of their dwelling unit. The paper determined three lifestyles in Erbil city about the income groups that were reflected in the dwelling unit's component (the existence of dining room and dining furniture) and the pattern of family living in terms of social relations within single-family and the neighbors. The study concluded that there is a strong relationship among family members and with the neighbors, and the lifestyle is remarkably influenced by the families' income.

\section{INTRODUCTION}

The lifestyle is different based on the culture, region, country, etc. Therefore, a building or a space with special importance can represent artifacts in the built environment for a group of people based on their social relationships to be part of their lifestyle. Lifestyle can be directly manifested in the built environment through the form and layout of the dwelling unit to reflect economic and social value (Tognoli, 1987; Rapoport, 1969). Economic and cultural and social-political dimensions form undeniably the built environment. This indicates that the building, social and cultural principles have a wide and dynamic connection (Richardson, 1989). To understand the connection between people and the built environment, the relationship between human behavior and his culture in addition to physical environments needs to understand (Lang 1987). In other words, understanding the norms associated with the lifestyle. The study will focus on the relation with built environment by focusing 


\section{QALAAI ZANISTSCIENTIFIC JOURNAL \\ A Scientific Quarterly Refereed Journal Issued by Lebanese French University - Erbil, Kurdistan, Iraq \\ Vol. (5), No (2), Spring 2020 \\ ISSN 2518-6566 (Online) - ISSN 2518-6558 (Print)}

on interior architecture. Interior architecture is the combination of the art and science of the interior design and takes all elements of the structure into account (Coles and House, 2007). In terms of practice and philosophy, Interior architecture is a field that plays a significant role in the renovation and reconstruction of existing buildings and it is significantly affected by the lifestyle of the occupants.

The paper is part of bigger study (master thesis) in interior architecture. The paper aims to evaluate the lifestyle factors for interior design in residential buildings in Erbil, to direct interior architects and designers on suitable design in the interior design as per the income of the family in Iraqi Kurdistan. The objectives of the study will be as follow; 1) Identifying the characteristic of the interior architecture inside residential buildings in Erbil-Kurdistan of Iraq based on the people lifestyle; 2) Evaluation of the performance of lifestyle in interior spaces of dwelling units in Erbil; 3) Finding the relationships in the lifestyle among different income families inside the dwelling units in Erbil. The study area is in the Kurdistan region, which is a federated state situated within the Federal Republic of Iraq under the Iraqi Constitution, Article 62. It is situated in Iraq's north-east and Erbil is its capital. The study area was chosen because of the specific characteristics that make it distinctive, which consequently affects people's lifestyles. Kurdistan region is located among three big empires or cultures, namely; Arabic, Turkish, and Persian. By its position among Turkey, Iran, and the rest of Arabic Iraq, the Kurdistan Region of Iraq is holding a particular type through interrelation with all these cultural bodies (Meho, 1997). See figure ' 1 '. 


\section{QALAAI ZANISTSCIENTIFIC JOURNAL}

A Scientific Quarterly Refereed Journal Issued by Lebanese French University - Erbil, Kurdistan, Iraq

Vol. (5), No (2), Spring 2020

ISSN 2518-6566 (Online) - ISSN 2518-6558 (Print)

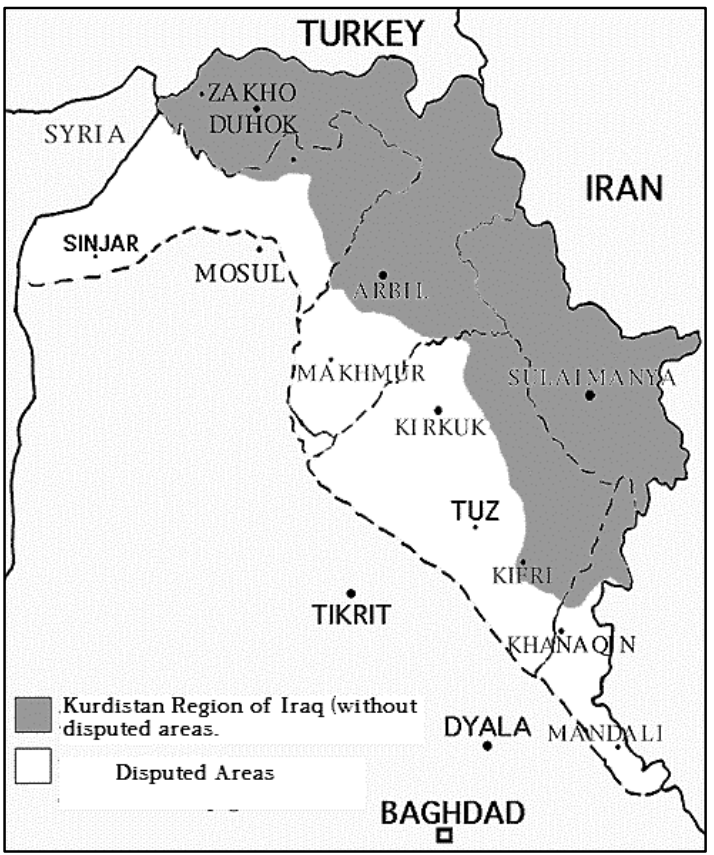

Figure 1. Northern Iraq (Kurdistan region of Iraq). Source:

https://inmutualweirdness.com/practical-travel-info/practical-travel-information/kurdistantravel-info/maps-of-kurdistan/

\subsection{The Concept of Lifestyle}

The word (Lifestyle) is generally mentioned in media and environmental and wellness researches. It seems like it is just life or way of life that is taken for granted. In Sociological view, Lifestyle means a person, a group, or a culture's interests, views, behavior, and acts (Kahle and Close, 2011). The issue with the lifestyle concept is that it is not specified at all or specified in several ways. Many (social) scholars use the lifestyle concept in order to explain how you live or want to lead your life (Pulkkinen \& Kokko in 2000), which is related to a lifestyle. Some 


\section{QALAAI ZANISTSCIENTIFIC JOURNAL \\ A Scientific Quarterly Refereed Journal Issued by Lebanese French University - Erbil, Kurdistan, Iraq \\ Vol. (5), No (2), Spring 2020 \\ ISSN 2518-6566 (Online) - ISSN 2518-6558 (Print)}

others say that lifestyle is the number of factors associated with wellbeing (such as smoking, alcohol, drugs, fat, sugar, exercise) (Cockerham 2002; Bolt, 2002). Other scholars address the Lifestyle is the manifestation of a world consumption class (Connolly and Prothero 2003; Stoll-Kleemann et al. 2001).

\subsection{Factors Influencing Lifestyle}

The literature was surveyed to formulate initial factors for assessing lifestyle. Several studies have been done on lifestyle and have identified factors for their assessment. The study would concentrate on the types of the researches related to the area of the research such as urbanism and architecture. Lufkin et al., (2018) noted that in the future community the life quality depends largely on its design and programming so that the various populations can consider the required elements for developing lifestyles of their own. These components are based on six key dimensions which are; physical, psychological, social, spiritual, traditional, and technological. In more details and based on other researches by (Sidawi, 2008; Lufkin et al., 2018), they defined lifestyle as per the local traditions and the main principles which can be summarized as follows:

- Physical aspects: the necessity to have a convenient room in terms of configuration, scale, area, dimension, shape, etc.

- Psychological aspects: the need for space that offers comfort by using color, separation, type of connection with other indoor areas and connection to outdoor areas, etc. Spaces must give users a sense of privacy and safety. 


\section{QALAAI ZANISTSCIENTIFIC JOURNAL}

A Scientific Quarterly Refereed Journal Issued by Lebanese French University - Erbil, Kurdistan, Iraq

Vol. (5), No (2), Spring 2020

ISSN 2518-6566 (Online) - ISSN 2518-6558 (Print)

- Social aspects: the people required the space to communicate with their family, relations, hosts, neighbors, and friends.

- Spiritual aspects: the necessity for a space to work out spiritually, praise, and lovemaking. also, a different way of describing lifestyle as to how a person is living and working and influencing other aspects, such as culture, community, and technology to provide a better life for human beings (Huang, 2011).

- Traditional Dimension: it includes the way of selecting and spreading the furniture and most repetitive and preferable habits and activities according to the community's habits and tradition.

- Technological Dimension: It involves the applied materials and technologies in the construction process in pre-occupancy periods, and the furniture or other technological tools that are using by the people in the postoccupancy period, as shown in table ' 1 '.

Table 1. The lifestyle characteristics and the qualitative and quantitative measurement factors. (Developed by researcher).

\begin{tabular}{|l|l|l|l|l|l|l|}
\hline No & $\begin{array}{l}\text { Lifestyle } \\
\text { characteristi } \\
\text { c }\end{array}$ & $\begin{array}{l}\text { Quantitative } \\
\text { factors } \\
\text { measureme } \\
\text { nts }\end{array}$ & $\begin{array}{l}\text { Measuremen } \\
\text { t tools }\end{array}$ & $\begin{array}{l}\text { Qualitative } \\
\text { factors } \\
\text { measureme } \\
\text { nts }\end{array}$ & $\begin{array}{l}\text { Measuremen } \\
\text { t tools }\end{array}$ & $\begin{array}{l}\text { Referenc } \\
\text { es }\end{array}$ \\
\hline 1 & $\begin{array}{l}\text { Physical } \\
\text { Dimension }\end{array}$ & $\begin{array}{l}\text { size, area, } \\
\text { dimensions, } \\
\text { shape, form }\end{array}$ & $\begin{array}{l}\text { Observation } \\
\text { s and direct } \\
\text { measureme } \\
\text { nt, }\end{array}$ & $\begin{array}{l}\text { Comfortabl } \\
\text { e space }\end{array}$ & $\begin{array}{l}\text { Questionnai } \\
\text { re or } \\
\text { interview }\end{array}$ & $\begin{array}{l}\text { (Sidawi, } \\
\text { 2008) }\end{array}$ \\
\hline
\end{tabular}




\begin{tabular}{|c|c|c|c|c|c|c|}
\hline & & & $\begin{array}{l}\text { documentar } \\
\text { y analysis }\end{array}$ & & & \\
\hline 2 & $\begin{array}{l}\text { Psychologic } \\
\text { al } \\
\text { Dimension }\end{array}$ & $\begin{array}{l}\text { 1.Color, } \\
2 . \\
\text { Isolation, } \\
\text { 3. Link with } \\
\text { other } \\
\text { internal } \\
\text { spaces and } \\
\text { 4. Link with } \\
\text { the outdoor } \\
\text { spaces. }\end{array}$ & $\begin{array}{l}\text { Observation } \\
\text { s and direct } \\
\text { measureme } \\
\mathrm{nt} \text {, } \\
\text { documentar } \\
\text { y analysis }\end{array}$ & $\begin{array}{l}\text { 1. Feeling } \\
\text { of } \\
\text { relaxation } \\
\text { 2. Security } \\
\text { and safety } \\
\text { feelings }\end{array}$ & $\begin{array}{l}\text { Questionnai } \\
\text { re or } \\
\text { interview }\end{array}$ & $\begin{array}{l}\text { (Sidawi, } \\
\text { 2008); } \\
\text { (Lufkin } \\
\text { et al., } \\
\text { 2018) }\end{array}$ \\
\hline 3 & $\begin{array}{l}\text { Social } \\
\text { Dimension }\end{array}$ & $\begin{array}{l}\text { 1. Space for } \\
\text { an } \\
\text { individual } \\
\text { to socialize } \\
\text { 1. with } \\
\text { family, } \\
\text { 2. with } \\
\text { relatives, } \\
\text { 3. with } \\
\text { guests, and } \\
\text { 4. with } \\
\text { neighbors }\end{array}$ & $\begin{array}{l}\text { Observation } \\
\text { s and direct } \\
\text { measureme } \\
\mathrm{nt} \text {, } \\
\text { documentar } \\
\text { y analysis }\end{array}$ & $\begin{array}{l}\text { Social and } \\
\text { friendship } \\
\text { feeling }\end{array}$ & $\begin{array}{l}\text { Questionnai } \\
\text { re or } \\
\text { interview }\end{array}$ & $\begin{array}{l}\text { (Sidawi, } \\
\text { 2008), } \\
\text { (Lufkin } \\
\text { et al., } \\
\text { 2018) }\end{array}$ \\
\hline
\end{tabular}




\section{QALAAI ZANISTSCIENTIFIC JOURNAL}

A Scientific Quarterly Refereed Journal Issued by Lebanese French University - Erbil, Kurdistan, Iraq

Vol. (5), No (2), Spring 2020

ISSN 2518-6566 (Online) - ISSN 2518-6558 (Print)

\begin{tabular}{|c|c|c|c|c|c|c|}
\hline 4 & $\begin{array}{l}\text { Spiritual } \\
\text { Dimension }\end{array}$ & $\begin{array}{l}\text { A space for } \\
\text { spiritual } \\
\text { practice, } \\
\text { worship } \\
\text { and } \\
\text { adoration. }\end{array}$ & $\begin{array}{l}\text { Observation } \\
\text { s and direct } \\
\text { measureme } \\
\mathrm{nt} \\
\text { documentar } \\
\text { y analysis }\end{array}$ & $\begin{array}{l}\text { Spiritual } \\
\text { feeling }\end{array}$ & $\begin{array}{l}\text { Questionnai } \\
\text { re or } \\
\text { interview }\end{array}$ & $\begin{array}{l}\text { (Sidawi, } \\
\text { 2008) }\end{array}$ \\
\hline 5 & $\begin{array}{l}\text { Traditional } \\
\text { Dimension }\end{array}$ & $\begin{array}{l}\text { 1.Furniture } \\
\text { types } \\
\text { 2. The way } \\
\text { of } \\
\text { spreading } \\
\text { the } \\
\text { furniture. } \\
\text { 3. Daily } \\
\text { repetitive } \\
\text { habits/ } \\
\text { activities of } \\
\text { the family. }\end{array}$ & $\begin{array}{l}\text { Observation } \\
\mathrm{s} \\
\text { questionnair } \\
\text { e, and } \\
\text { interview }\end{array}$ & $\begin{array}{l}\text { Satisfactory } \\
\text { feeling }\end{array}$ & $\begin{array}{l}\text { Questionnai } \\
\text { re or } \\
\text { interview }\end{array}$ & $\begin{array}{l}\text { (Huang, } \\
\text { 2011) }\end{array}$ \\
\hline 6 & $\begin{array}{l}\text { Technology } \\
\text { Dimension }\end{array}$ & $\begin{array}{l}\text { 1. Physical } \\
\text { building } \\
\text { material } \\
\text { technology } \\
\text { (constructio } \\
\text { n material, } \\
\text { furniture }\end{array}$ & $\begin{array}{l}\text { Observation } \\
\mathrm{s} \\
\text { questionnair } \\
\mathrm{e} \text {, and } \\
\text { interview }\end{array}$ & $\begin{array}{l}\text { Social } \\
\text { strength or } \\
\text { weakness } \\
\text { feeling }\end{array}$ & $\begin{array}{l}\text { Questionnai } \\
\text { re or } \\
\text { interview }\end{array}$ & $\begin{array}{l}\text { (Huang, } \\
2011 \text { ) }\end{array}$ \\
\hline
\end{tabular}




\begin{tabular}{|l|l|l|l|l|}
\hline & $\begin{array}{l}\text { materials, } \\
\text { services). } \\
\text { 2. } \\
\text { Accessibility } \\
\text { technology } \\
\text { (Social } \\
\text { include } \\
\text { media, } \\
\text { telephone, } \\
\text { and } \\
\text { Physical, } \\
\text { include } \\
\text { automobile } \\
\text { s, bike, } \\
\text { bicycles) }\end{array}$ & & & \\
& & & \\
\hline
\end{tabular}

\section{LITERATURE REVIEW}

The literature review has conducted several previous studies about the relationship between interior architecture and lifestyle to formulate the main outline of this study. Al-Homoud et al., (2010), have studied the effect of the change in lifestyle on the living buildings of the Bedouin in Northeastern Badia of Jordan, through applying six levels which are; density, tranquility, conviviality, elitism, social anchoring, and family friendliness. This study tried to investigate the lifestyle effects on the socio-spatial scale. The study specified a link between lifestyle changing and socio-spatial scale. Results also suggested that the 


\section{QALAAI ZANISTSCIENTIFIC JOURNAL \\ A Scientific Quarterly Refereed Journal Issued by Lebanese French University - Erbil, Kurdistan, Iraq \\ Vol. (5), No (2), Spring 2020 \\ ISSN 2518-6566 (Online) - ISSN 2518-6558 (Print)}

associated with privacy is positively connected with factors of lifestyle, like social role, adherence to the local society, family size, the role of the male in the family, which positively affected territorial control. In another study, the effect of interior architecture on occupants' feelings in terms of comfort in a residential space has been studied. The participation of ' 32 ' occupants in a survey using virtual reality ambiances which contain different collections of interior design elements. The study has taken the affordance and satisfaction as a measure of the occupants feeling of comfort. The study demonstrated that the realized affordance of elements in interior design was affected positively by priming and concrete conducts in the inner space. In the same context, surfaces, materials, and colors have participated very weakly to clear feelings about the space by occupants (Lee et al., 2017). Rashdan (2016), is tried to explore the relation between smart design and sustainable lifestyle through interior design. This study has reviewed the theoretical notion behind smart design and sustainability, investigating the benefits of interior design solutions with smart technologies on a sustainable lifestyle. The study showed that involving smart technologies into interior design has a positive impact on sustainable lifestyle aspects in terms of environmental, economic, and socio-cultural levels.

A study approached by Mahmoud (2014), inspect the factors that are predicted to be more effective positively in the relation between interior architectural design and the behavior of residents and buildings' users. The study found that the successful interior design for implementing the well-being depends on several dominant factors; privacy, identity, accessibility, safety, functionality, flexibility, 


\section{QALAAI ZANISTSCIENTIFIC JOURNAL \\ A Scientific Quarterly Refereed Journal Issued by Lebanese French University - Erbil, Kurdistan, Iraq \\ Vol. (5), No (2), Spring 2020 \\ ISSN 2518-6566 (Online) - ISSN 2518-6558 (Print)}

interaction with the society, and provide a suitable inner space. Finally, the interior design judged by the design achievement based on the values, preferences, needs, and contentment of the occupants. A study about the welfare and well-being of occupants and its relationship with interior architecture through two main factors, namely; spatial size, and spatial form. The results of the study have shown the important association between spatial size (e.g. distance, depth, and height) and overall amenity level. It is also found that the spatial form (the ratio of width to depth, the ratio of height to the area, and the spatial volume) will affect the overall welfare considerably. The study concluded that spatial size and spatial shape have a significant influence on the amenity and welfare of the occupants (Lee and Wohn, 2016). Different levels of relationship between interior architecture and human behavior or lifestyle have been studied each of which demonstrated several indicators or factors for evaluation as seen in table ' 2 '.

Table 2. The dimension and the indicators with the outcomes of the reviewed studies in literature. (Developed by Researcher).

\begin{tabular}{|l|l|l|l|}
\hline $\begin{array}{l}\text { The dimension of } \\
\text { the relationship } \\
\text { between lifestyle } \\
\text { and interior } \\
\text { architecture }\end{array}$ & $\begin{array}{l}\text { Indicators or } \\
\text { factors for } \\
\text { evaluation }\end{array}$ & The outcome & References \\
\hline $\begin{array}{l}\text { Socio-cultural } \\
\text { dimension }\end{array}$ & $\begin{array}{l}\text { Density, } \\
\text { tranquility, } \\
\text { conviviality, } \\
\text { elitism, social } \\
\text { anchoring and }\end{array}$ & $\begin{array}{l}\text { The study concluded that } \\
\text { the privacy is positively } \\
\text { connected with factors of } \\
\text { lifestyle, like social role, } \\
\text { adherence to the local } \\
\text { society, family size, and the }\end{array}$ & $\begin{array}{l}\text { (Al-Homoud } \\
\text { et al., 2010) }\end{array}$ \\
\hline
\end{tabular}




\section{QALAAI ZANISTSCIENTIFIC JOURNAL}

A Scientific Quarterly Refereed Journal Issued by Lebanese French University - Erbil, Kurdistan, Iraq

Vol. (5), No (2), Spring 2020

ISSN 2518-6566 (Online) - ISSN 2518-6558 (Print)

\begin{tabular}{|c|c|c|c|}
\hline & $\begin{array}{l}\text { family } \\
\text { friendliness }\end{array}$ & $\begin{array}{l}\text { role of the male in the } \\
\text { family, which positively } \\
\text { affected territorial control. }\end{array}$ & \\
\hline $\begin{array}{l}\text { Comfort \& } \\
\text { efficiency } \\
\text { dimension }\end{array}$ & $\begin{array}{l}\text { Affordance and } \\
\text { satisfaction }\end{array}$ & $\begin{array}{l}\text { The study has showed that } \\
\text { the realized affordance of } \\
\text { elements in interior design } \\
\text { was affected positively by } \\
\text { priming and concrete } \\
\text { conducts in the inner space, } \\
\text { while, surfaces, materials, } \\
\text { and colors have participated } \\
\text { very weakly to clear feelings } \\
\text { about the space by } \\
\text { occupants. }\end{array}$ & $\begin{array}{l}\text { (Lee et al., } \\
\text { 2017) }\end{array}$ \\
\hline $\begin{array}{l}\text { Sustainability \& } \\
\text { technology } \\
\text { dimension }\end{array}$ & $\begin{array}{l}\text { The investigation } \\
\text { of the benefits of } \\
\text { interior design } \\
\text { solutions with } \\
\text { smart } \\
\text { technologies }\end{array}$ & $\begin{array}{l}\text { The study found, the } \\
\text { involving of smart } \\
\text { technologies into interior } \\
\text { design has a positive impact } \\
\text { on sustainable lifestyle } \\
\text { aspects in terms of } \\
\text { environmental, economic, } \\
\text { and socio-cultural levels. }\end{array}$ & $\begin{array}{l}\text { (Rashdan, } \\
\text { 2016) }\end{array}$ \\
\hline $\begin{array}{l}\text { Psychological } \\
\text { dimension }\end{array}$ & $\begin{array}{l}\text { Privacy, identity, } \\
\text { accessibility, } \\
\text { safety, } \\
\text { functionality, } \\
\text { flexibility, } \\
\text { interaction with } \\
\text { the society, and }\end{array}$ & $\begin{array}{l}\text { The interior architectural } \\
\text { design should be judged by } \\
\text { the design achievement } \\
\text { based on the values, } \\
\text { preferences, needs, and } \\
\text { contentment of the } \\
\text { occupants, in addition to } \\
\text { giving valuable weight for }\end{array}$ & $\begin{array}{l}\text { (Mahmoud, } \\
\text { 2014) }\end{array}$ \\
\hline
\end{tabular}




\section{QALAAI ZANISTSCIENTIFIC JOURNAL}

A Scientific Quarterly Refereed Journal Issued by Lebanese French University - Erbil, Kurdistan, Iraq

Vol. (5), No (2), Spring 2020

ISSN 2518-6566 (Online) - ISSN 2518-6558 (Print)

\begin{tabular}{|c|c|c|c|}
\hline & $\begin{array}{l}\text { provide a suitable } \\
\text { inner space }\end{array}$ & $\begin{array}{l}\text { the indicators have } \\
\text { mentioned in the study. }\end{array}$ & \\
\hline $\begin{array}{l}\text { Welfare and well- } \\
\text { being dimensions }\end{array}$ & $\begin{array}{l}\text { the spatial size } \\
\text { (width, depth, } \\
\text { and height) the } \\
\text { spatial shape (the } \\
\text { width-to-depth } \\
\text { ratio, the height- } \\
\text { to-area ratio, and } \\
\text { room shape) }\end{array}$ & $\begin{array}{l}\text { The study concluded that } \\
\text { spatial size and spatial } \\
\text { shape have significant } \\
\text { influence on Amenity of } \\
\text { occupant }\end{array}$ & $\begin{array}{l}\text { (Lee and } \\
\text { Wohn, 2016) }\end{array}$ \\
\hline
\end{tabular}

\subsection{The significance of the study}

The research focuses on the connection between lifestyle and the income of the families in Erbil city in Kurdistan of Iraq. This research's importance stems from its cultural context that was not extensively studied in the region of study. This study is significant to help the professionals to influence the clients in their building design solution.

\subsection{The Problem of the study}

The lack of awareness about the relationship between lifestyle and family income led to having a low understanding of the effect of family income on interior architecture in terms of dwelling units' components. According to the literature review, there is a lack of studies in the Kurdistan region of Iraq regarding the relationship between lifestyle and interior architecture. Furthermore, as has been demonstrated in the literature review, there are no enough types of research 


\section{QALAAI ZANISTSCIENTIFIC JOURNAL \\ A Scientific Quarterly Refereed Journal Issued by Lebanese French University - Erbil, Kurdistan, Iraq \\ Vol. (5), No (2), Spring 2020 \\ ISSN 2518-6566 (Online) - ISSN 2518-6558 (Print)}

regarding the effectiveness of the income on interior architecture and the lifestyle in the region of study. Thus, when architects and interior designers get a comprehensive understanding of the income of the client they will delineate or perceive their lifestyle. This may let them be more aware of the optimum design process to achieve the families' requirements in Erbil.

\subsection{The Questions of the Study}

The paper tries to answer the following main questions; How can we evaluate lifestyle in interior architecture in Erbil-Kurdistan of Iraq? And this is through the following sub-questions 1) What are lifestyle characteristics of dwelling units' components based on the group income in Erbil- Kurdistan of Iraq? 2) What are the similarities and differences among lifestyle inside the residential buildings in Erbil-Kurdistan Region of Iraq based on the families' income?

\section{METHODOLOGY}

To tackle the research questions and objectives, the study approached the qualitative and quantitative research methods. The following procedure has been applied to reach the research aims and objectives. These include;

1) Review of the literature that relevant carried out by other researchers to gain a suggestion for improvement, in addition to searching key relevant books, journals, and credible net sources related to the field; 2) Field observation has been approached as part of the quantitative method; 3) Questionnaire has been developed as part of both quantitative and qualitative methods. Consequently, an 


\section{QALAAI ZANISTSCIENTIFIC JOURNAL \\ A Scientific Quarterly Refereed Journal Issued by Lebanese French University - Erbil, Kurdistan, Iraq \\ Vol. (5), No (2), Spring 2020 \\ ISSN 2518-6566 (Online) - ISSN 2518-6558 (Print)}

analysis of the previous elements have applied based on positive and negative correlation based on the cause and effect that been conducted.

Therefore, a case study methodology is used for the implementation of this goal. Thirty houses have been selected in different sectors of Erbil, divided into three categories (Low-income, Mid-income, and High-income) based on the income of each family. According to the collected data from governmental authorities in the Kurdistan region of Iraq, Case studies have been selected based on High, mid, and low-income householders. Nearly $36 \%$ of households in Kurdistan region of Iraq have a monthly income of less than 500,000 Iraqi Dinars (IQD) per month, which are considered low-income householders; over $51 \%$ an average monthly income of $500,000-1,000,000$ IQD per month, and they considers as mid-income; and 13\% of households earn over 1,000,000 IQD per month, and they are represented as high income, (IOM, 2018). See table ' 3 '.

Table 3. Average monthly income for Low, Mid, and High income householders in Iraq. (IOM, 2018).

\begin{tabular}{|l|l|l|}
\hline No. & Income level & Average Monthly Household Income (IQD)* \\
\hline 1 & Low income & Upto 500,000 Iraqi Dinars (IQD) \\
\hline 2 & Mid income & $500,000-1,000,000$ IQD \\
\hline 3 & High income & $1,000,000$ IQD \\
\hline
\end{tabular}

*1 US\$=1,200 IQD

\subsection{Formulation of Measurable Factors of Lifestyle}




\section{QALAAI ZANISTSCIENTIFIC JOURNAL \\ A Scientific Quarterly Refereed Journal Issued by Lebanese French University - Erbil, Kurdistan, Iraq \\ Vol. (5), No (2), Spring 2020 \\ ISSN 2518-6566 (Online) - ISSN 2518-6558 (Print)}

Based on the literature review and the initial factors of lifestyle as shown in table ' 1 '. The most measurable factors in the region of study have been determined. The selected factors should be characterized by the possibility of either measure them through direct observation or assess them based on the feeling or opinion of the people. Moreover, the selected factors have been chosen based on their effect on the three main dimensions of sustainability (environmental, economic, and social). Therefore, based on this concept, the lifestyle factors that can be evaluated had been extracted from the literature as seen in table ' 4 '.

Table 4. The general Lifestyle factors that can be evaluated in the current study. (Developed by researcher).

\begin{tabular}{|l|l|l|l|l|}
\hline No & $\begin{array}{l}\text { Factors to be used in } \\
\text { testing lifestyle }\end{array}$ & Reason & $\begin{array}{l}\text { Dimensions or } \\
\text { Levels }\end{array}$ & $\begin{array}{l}\text { Measurement } \\
\text { tools }\end{array}$ \\
\hline 1 & $\begin{array}{l}\text { size, area, } \\
\text { dimensions, shape, } \\
\text { form, and Isolation, }\end{array}$ & $\begin{array}{l}\text { To understand } \\
\text { the comfort } \\
\text { level and the } \\
\text { well-being } \\
\text { condition for } \\
\text { the residential } \\
\text { buildings. Then } \\
\text { to evaluate } \\
\text { lifestyle grade }\end{array}$ & $\begin{array}{l}\text { Comfort and } \\
\text { safety (physical } \\
\text { levels) }\end{array}$ & $\begin{array}{l}\text { Observation, } \\
\text { measurement, } \\
\text { and } \\
\text { documentary } \\
\text { analysis }\end{array}$ \\
\hline 2 & $\begin{array}{l}\text { 1.Color, } \\
\text { 2. interior spaces } \\
\text { (Links among } \\
\text { internal spaces)- }\end{array}$ & $\begin{array}{l}\text { They are main } \\
\text { factors to be } \\
\text { studied in }\end{array}$ & $\begin{array}{l}\text { Social } \\
\text { interrelations } \\
\text { and friendship, } \\
\text { plus satisfactory }\end{array}$ & $\begin{array}{l}\text { Observation, } \\
\text { measurement, } \\
\text { and } \\
\text { documentary }\end{array}$ \\
\hline
\end{tabular}




\section{QALAAI ZANISTSCIENTIFIC JOURNAL}

A Scientific Quarterly Refereed Journal Issued by Lebanese French University - Erbil, Kurdistan, Iraq

Vol. (5), No (2), Spring 2020

ISSN 2518-6566 (Online) - ISSN 2518-6558 (Print)

\begin{tabular}{|l|l|l|l|}
\hline $\begin{array}{l}\text { How an individual is } \\
\text { socializing with } \\
\text { a. family, }\end{array}$ & $\begin{array}{l}\text { interior } \\
\text { architecture } \\
\text { b. relatives, }\end{array}$ & $\begin{array}{l}\text { feelings (Social } \\
\text { \& Traditional } \\
\text { Levels) }\end{array}$ & $\begin{array}{l}\text { analysis, as } \\
\text { well as } \\
\text { questionnaire }\end{array}$ \\
$\begin{array}{l}\text { c. guests } \\
\text { 3. Furniture types } \\
\text { 4. The way of } \\
\text { spreading the } \\
\text { furniture. }\end{array}$ & & \\
\end{tabular}

It is obvious that many indicators exist for determining lifestyle in the literature. However, the measurable indicators with respect to the study limits will be employed in the evaluating lifestyle in the study area, as will be seen in the next section.

\subsection{Study area and Case study Selection}

\subsubsection{Study Area}

Erbil is an ancient city dated back to 6000 BC (Khalid, 2014) and located in the Kurdistan region of Iraq (Khalid, 2014). Newly, Erbil, as well as the Kurdistan region, has seen significant developments made to the extending of urbanization and growing in the housing sector (Amin and Muhy Al-din, 2018). The city has an area of 130 (square kilometer). Erbil urban region has inhabitants of 1,026,000, making 


\section{QALAAI ZANISTSCIENTIFIC JOURNAL}

A Scientific Quarterly Refereed Journal Issued by Lebanese French University - Erbil, Kurdistan, Iraq

Vol. (5), No (2), Spring 2020

ISSN 2518-6566 (Online) - ISSN 2518-6558 (Print)

it one of Iraq's biggest cities. Erbil is located in a plain region relatively, with a median height from the sea level of 426 meters (Fadhil, 2011). It is far by 88 kilometers from Mosul, and 367 kilometers from Baghdad, the capital of Iraq. Erbil city has a geographical coordinate $\left(36^{\circ} 11^{\prime} 28^{\prime \prime} \mathrm{N} 44^{\circ} 0^{\prime} 33^{\prime \prime} \mathrm{E}\right)$, and it is positioned in the eastern north of Iraq. (Saeed, 2003). See figure ' 2 '.

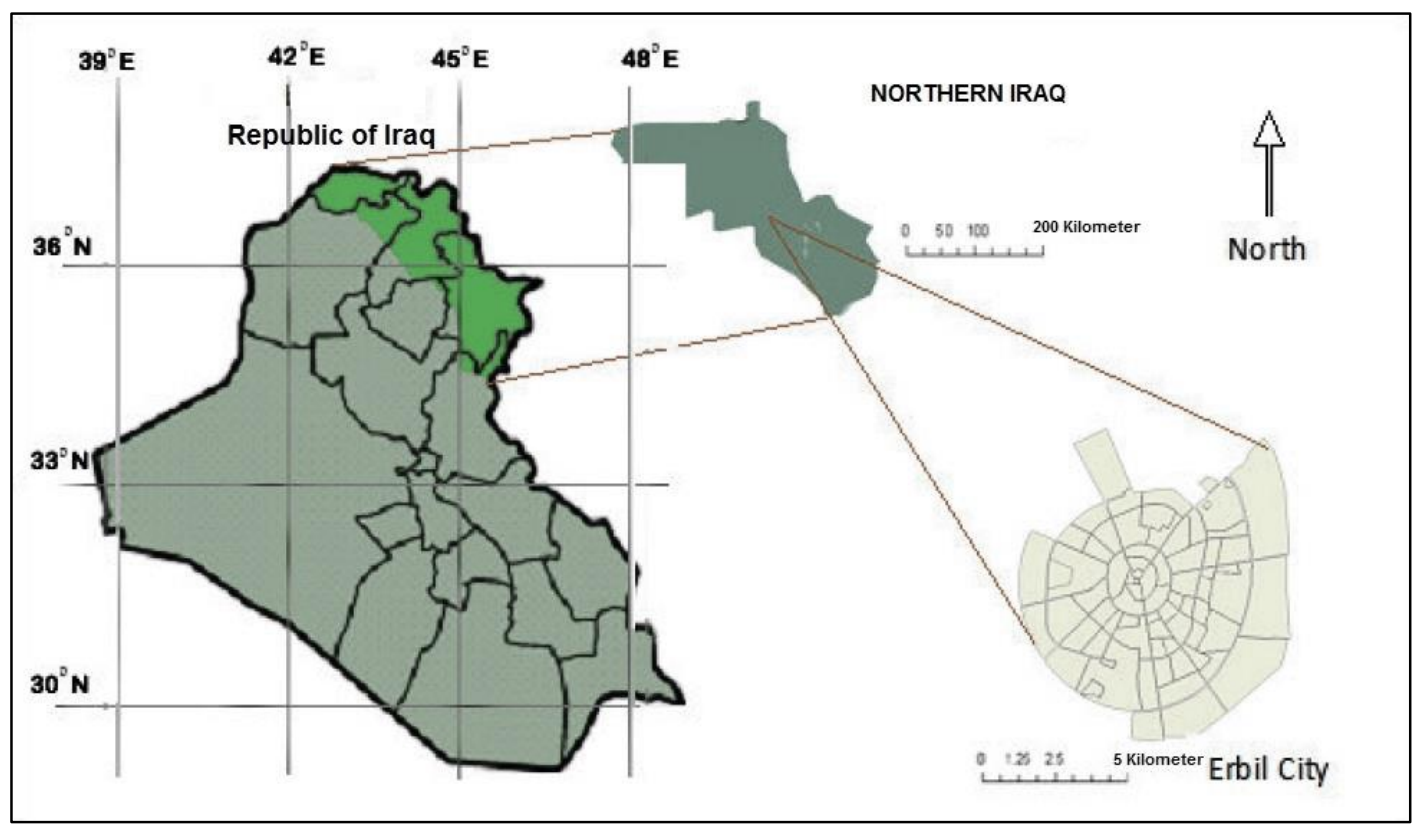

Figure 2. Location of Erbil in Iraq. (Khalid, 2014). 


\section{QALAAI ZANISTSCIENTIFIC JOURNAL \\ A Scientific Quarterly Refereed Journal Issued by Lebanese French University - Erbil, Kurdistan, Iraq \\ Vol. (5), No (2), Spring 2020 \\ ISSN 2518-6566 (Online) - ISSN 2518-6558 (Print)}

The average domestic size in KRI (Kurdistan Region of Iraq) is 5.1 members, according to the overall data. To understand the conditions of the family structure in Kurdistan of Iraq it is important to highlight some data regarding this. Around $35 \%$ of the population is under the age of 15 years, almost $60 \%$ of the community is $15-65$ years of age and $5 \%$ are over 65 years of age. The KRI family currently enjoys an acceptable standard of living, almost all of whom are fitted with the most common household appliances (television, furnace, and refrigerator). (KRI families are also equipped with the latest equipment). $3 / 4$ of the families owned the house which they reside in, and have sanitation systems in public water $(90 \%)$ and electricity networks. $87 \%$ of households have monthly incomes of less than $1,000,000$ Iraqis (approximately US\$ 835 ). $50 \%$ of the KRI population aged 18-64 years is employed in the public sector (IOM, 2018).

\subsubsection{The selection of Case study buildings}

Despite the difficulties to deal with the families and interfere in their private life and enter their houses, because of the conservative nature of the society in Erbil, and in Kurdistan of Iraq, the researcher has been able to select thirty houses as case study buildings in the current study. Ten houses from each income level have been selected from different places like (Qalan Chokhan, Ankawa, Wazeran, Andaziaran, Zanko, etc.) in Erbil city to be observed and analyzed. Figures ' 3 ' show examples from each classified groups of houses for (Low, Mid, and High) incomes. Spatial configuration of the case studies has been analyzed through coding important spaces in the houses. The significant spaces was, kitchen (coded by '1'), 


\section{QALAAI ZANISTSCIENTIFIC JOURNAL}

A Scientific Quarterly Refereed Journal Issued by Lebanese French University - Erbil, Kurdistan, Iraq

Vol. (5), No (2), Spring 2020

ISSN 2518-6566 (Online) - ISSN 2518-6558 (Print)

Family Lounge (Coded by ' 2 '), Bedrooms (coded by ' 3 '), and guest rooms (Coded by ' 4 ').

\begin{tabular}{|c|c|c|c|}
\hline $\begin{array}{c}\text { Income level \& } \\
\text { (Location) }\end{array}$ & $\begin{array}{c}\text { Location of the house within } \\
\text { Erbil }\end{array}$ \\
$\begin{array}{c}\text { Low- } \\
\text { income } \\
\text { (Qaland Chokhan) }\end{array}$ & facade & \\
\hline $\begin{array}{c}\text { Mid- income } \\
\text { (Ankawa) }\end{array}$ & Spatial configuration \\
\hline $\begin{array}{c}\text { High- } \\
\text { income } \\
\text { (Waziran) }\end{array}$ & & & \\
\hline
\end{tabular}

Figure 3. Three types of dwelling units in Erbil based on the family's income. (Developed by Researcher).

The obtained data demonstrated that $60 \%$ of the selected residential buildings ( 30 houses) are row houses, 30 percent are semi-detached houses, and 10\% of them are detached houses, while no any apartment has been selected because the study is focusing on the houses as a most prevailed type of residential buildings in Kurdistan of Iraq recently. See figure ' 4 '. 


\section{QALAAI ZANISTSCIENTIFIC JOURNAL}

A Scientific Quarterly Refereed Journal Issued by Lebanese French University - Erbil, Kurdistan, Iraq

Vol. (5), No (2), Spring 2020

ISSN 2518-6566 (Online) - ISSN 2518-6558 (Print)

\section{Residency Category}

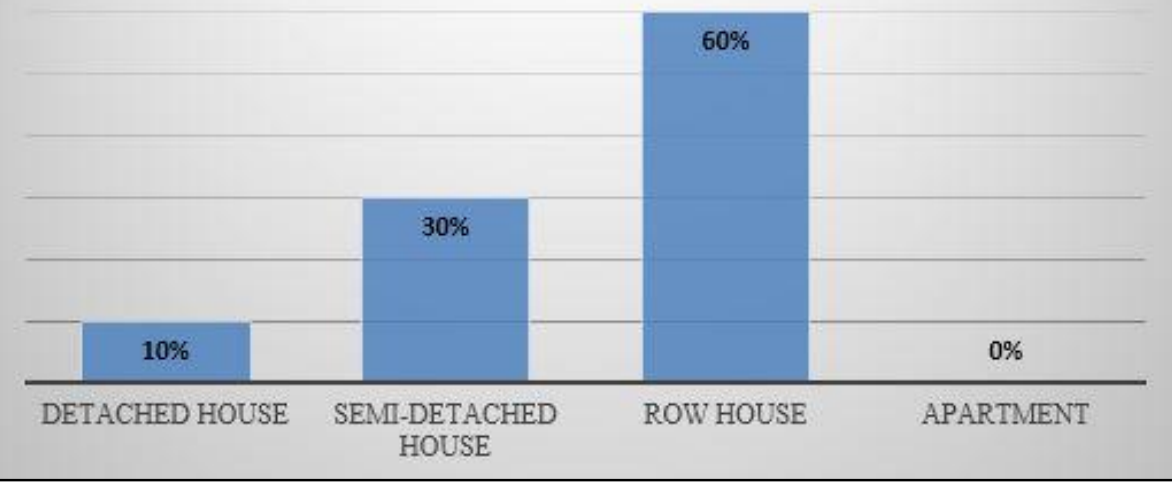

Figure 4. Type of residential buildings. (By researcher).

In this context, ten houses of each category have been selected to be analyzed. The measurable factors for the evaluation lifestyle in Erbil, with the respect to the limits of the current study, have been identified, which are in comfort and safety dimension, and in the social dimension, as seen in table ' 5 '.

Table 5. The Lifestyle factors that can be evaluated by Observations and Questionnaire. (Developed by Researcher)

\begin{tabular}{|l|l|l|l|l|}
\hline No & $\begin{array}{l}\text { Factors to be used in } \\
\text { testing lifestyle within } \\
\text { current study }\end{array}$ & Reason & $\begin{array}{l}\text { Dimensions or } \\
\text { Levels }\end{array}$ & $\begin{array}{l}\text { Measurement } \\
\text { tools }\end{array}$ \\
\hline 1 & $\begin{array}{l}\text { size, area, dimensions, } \\
\text { number of rooms, }\end{array}$ & $\begin{array}{l}\text { To understand } \\
\text { the comfort } \\
\text { level and the } \\
\text { well-being } \\
\text { condition for } \\
\text { the residential }\end{array}$ & $\begin{array}{l}\text { Comfort and } \\
\text { safety (physical \& } \\
\text { psychological } \\
\text { levels) }\end{array}$ & $\begin{array}{l}\text { Observation, } \\
\text { measurement, } \\
\text { and } \\
\text { documentary } \\
\text { analysis }\end{array}$ \\
\hline
\end{tabular}




\section{QALAAI ZANISTSCIENTIFIC JOURNAL}

A Scientific Quarterly Refereed Journal Issued by Lebanese French University - Erbil, Kurdistan, Iraq

Vol. (5), No (2), Spring 2020

ISSN 2518-6566 (Online) - ISSN 2518-6558 (Print)

\begin{tabular}{|c|c|c|c|c|}
\hline & & $\begin{array}{l}\text { buildings. Then } \\
\text { to evaluate } \\
\text { lifestyle grade }\end{array}$ & & \\
\hline 2 & $\begin{array}{l}\text { 1. Interior spaces (Links } \\
\text { among internal } \\
\text { spaces)- How an } \\
\text { individual is socializing } \\
\text { with } \\
\text { a. family, } \\
\text { b. neighbors, } \\
\text { c. inner zones }\end{array}$ & $\begin{array}{l}\text { They are main } \\
\text { factors to be } \\
\text { studied in } \\
\text { interior } \\
\text { architecture }\end{array}$ & $\begin{array}{l}\text { Social } \\
\text { interrelations } \\
\text { and friendship, } \\
\text { plus satisfactory } \\
\text { feelings (Social \& } \\
\text { Traditional } \\
\text { Levels) }\end{array}$ & $\begin{array}{l}\text { Observation, } \\
\text { measurement, } \\
\text { and } \\
\text { documentary } \\
\text { analysis, as } \\
\text { well as } \\
\text { questionnaire }\end{array}$ \\
\hline
\end{tabular}

Two main measurement tools have been used in the methodology of this study, namely; observation, and questionnaire. These ways have been conducted to assess lifestyle factors, as seen in table ' 5 '.

\section{FINDINGS \& DISCUSSION}

As mentioned previously, the measurement tools were observations and questionnaires. To evaluate the lifestyle, the comfort and safety based on the observation and questionnaire have been applied, as see table ' 5 '. This is through evaluating several factors, such as (Building's area, number of bedrooms, and availability of dining room, guest room, as well as family Lounge) in the different 


\section{QALAAI ZANISTSCIENTIFIC JOURNAL}

A Scientific Quarterly Refereed Journal Issued by Lebanese French University - Erbil, Kurdistan, Iraq

Vol. (5), No (2), Spring 2020

ISSN 2518-6566 (Online) - ISSN 2518-6558 (Print)

groups of the buildings. The results demonstrated that there are differences among the groups of the buildings that have been classified based on the householders' income. The differences were in the area of the buildings and the number of bedrooms, in addition to the availability of dining rooms and guest rooms. See Table '6'.

Table 6 . The comparison among low, mid, high incomes buildings regarding the well-being and comfort in the buildings, based on the dwelling unit's component.

\begin{tabular}{|l|l|l|l|l|l|}
\hline $\begin{array}{l}\text { Case study } \\
\text { buildings' } \\
\text { classification }\end{array}$ & $\begin{array}{l}\text { Range of } \\
\text { Areas of } \\
\text { Residential } \\
\text { buildings } \\
\text { for each } \\
\text { group }\left(\mathrm{m}^{2}\right)\end{array}$ & $\begin{array}{l}\text { Range of } \\
\text { the number } \\
\text { of Bed } \\
\text { Rooms }\end{array}$ & $\begin{array}{l}\text { Dinner } \\
\text { Room } \\
\text { availability } \\
(\%)\end{array}$ & $\begin{array}{l}\text { Guest } \\
\text { Room } \\
\text { availability } \\
(\%)\end{array}$ & $\begin{array}{l}\text { Family } \\
\text { Lounge } \\
\text { availability } \\
(\%)\end{array}$ \\
\hline Low- income & $100-178$ & $1-3$ & $10 \%$ & $70 \%$ & $100 \%$ \\
\hline Mid- income & $105-200$ & $2-3$ & $50 \%$ & $100 \%$ & $100 \%$ \\
\hline High- income & $250-500$ & $3-5$ & $100 \%$ & $100 \%$ & $100 \%$ \\
\hline
\end{tabular}

Table ' 5 ' can help to understand the crucial inner spaces in the daily life of the families in Erbil, to be as guidance to recognize the relationship between inner spaces and lifestyle of the families.

Another evaluation factor for the lifestyle was the social interrelation, and this has been evaluated based on interior spaces (Links among internal spaces). This part has been achieved based on spatial configuration analysis through coding 


\section{QALAAI ZANISTSCIENTIFIC JOURNAL}

A Scientific Quarterly Refereed Journal Issued by Lebanese French University - Erbil, Kurdistan, Iraq

Vol. (5), No (2), Spring 2020

ISSN 2518-6566 (Online) - ISSN 2518-6558 (Print)

important spaces in the houses. The reason is that these specific spaces are helping in studying the social interaction and movement gravity for the families inside the houses. The spatial configuration is demonstrated in figure ' 3 '.

Spatial configuration in figure ' 3 ', demonstrates the way of social living inside the houses, and how the people in Erbil as families are similar in their lifestyle regardless of the income or the grade of economic life. This is through the family lounge as connection inner space which collects the family and connects all the parts. Furthermore, the questionnaire has been asked the occupants about the most important place inside their dwelling units, and the feedback demonstrated that the most preferred place inside the home was the lounge. $54 \%$ of the participants like to spend the most time in this place, while $23 \%$ liked to spend their time in the kitchen. In the same regards, 14 percent preferred to spend their time in their private rooms, whereas, $9 \%$ preferred guest room as the most favorite place. See figure ' 5 '.

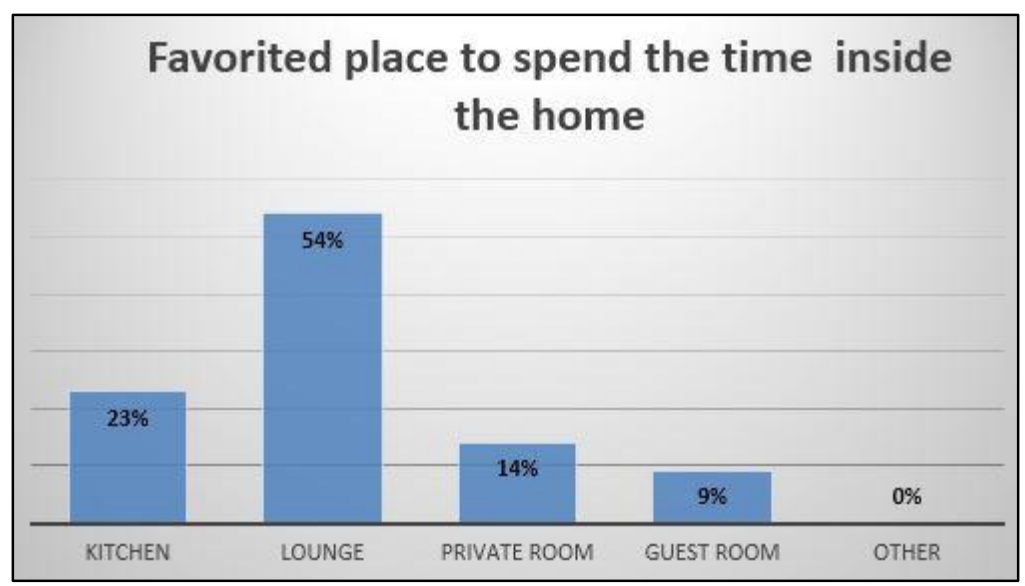




\section{QALAAI ZANISTSCIENTIFIC JOURNAL}

A Scientific Quarterly Refereed Journal Issued by Lebanese French University - Erbil, Kurdistan, Iraq

Vol. (5), No (2), Spring 2020

ISSN 2518-6566 (Online) - ISSN 2518-6558 (Print)

Figure 5. The most preferred place for the participants inside their houses. (By researcher).

The social relationship with neighbors has been tested as another factor to evaluate lifestyle. The relationship of people with their neighbors has been questioned directly to occupants based on the questionnaire form. See figure ' 6 '.

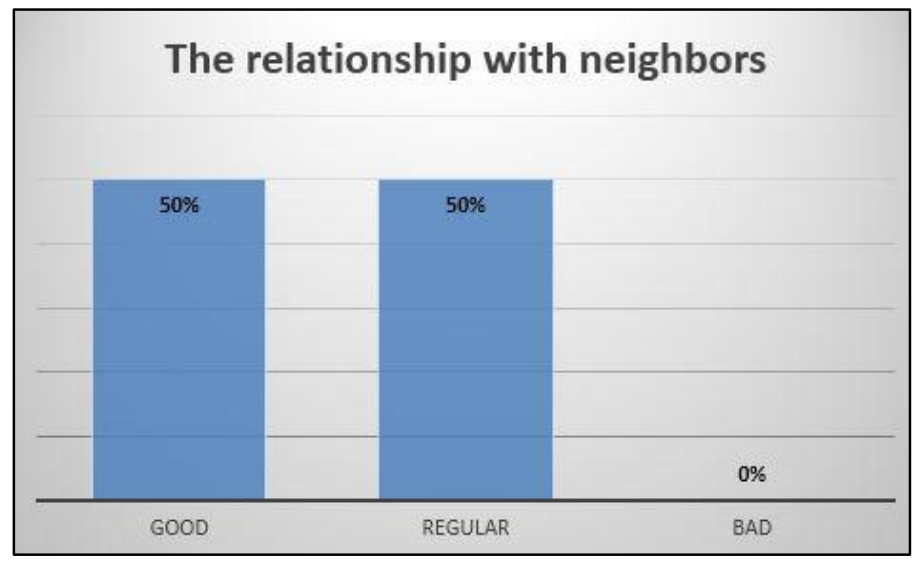

Figure 6. The relationship of the people with their neighbors. (By researcher).

The results demonstrated that $50 \%$ of the people have good relationship with their neighbors, and another $50 \%$ have regular relationship with them.

\section{CONCLUSION}

The study determined many dimensions to identify lifestyle characteristics. Measurable factors for evaluating lifestyle in the interior architecture of Erbil houses have been determined based on the literature review. See figure ' 7 '. 


\section{QALAAI ZANISTSCIENTIFIC JOURNAL}

A Scientific Quarterly Refereed Journal Issued by Lebanese French University - Erbil, Kurdistan, Iraq

Vol. (5), No (2), Spring 2020

ISSN 2518-6566 (Online) - ISSN 2518-6558 (Print)

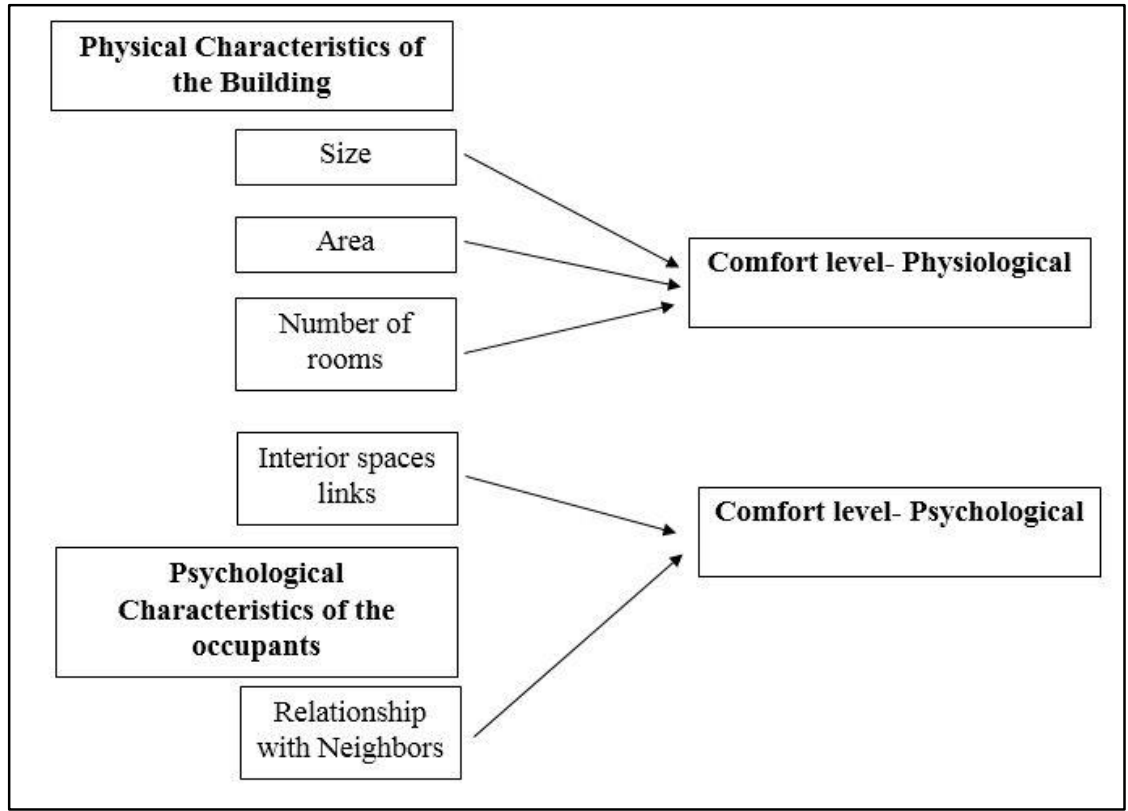

Figure 7. The main lifestyle evaluation factors. (Developed by researcher).

These factors have been tested in three categories of houses in Erbil (Low, mid, and high- income houses). Selected categories of houses were made to find repetitive or similar factors in each category and compare it with other categories to reach the lifestyle characteristic in Erbil. The study concluded that there is a strong correlation among the family member in Erbil. This was approved through, the shaping of the houses in such a shape making the family lounge as the most important part of the home. There are good relations among the families in Erbil. This was approved through the questionnaire to test the relation of the families with their neighbors. Furthermore, the study found that the majority of the houses having quest rooms. Despite the less usage for guest rooms, compared with family 


\section{QALAAI ZANISTSCIENTIFIC JOURNAL \\ A Scientific Quarterly Refereed Journal Issued by Lebanese French University - Erbil, Kurdistan, Iraq \\ Vol. (5), No (2), Spring 2020 \\ ISSN 2518-6566 (Online) - ISSN 2518-6558 (Print)}

lounge rooms or private rooms, but the people spending at least the number of hours in the guest rooms per week. This indicates that there is a strong social relationship among families. The study found that in Erbil, as much as the income of the people increases, the habit to have bigger houses and more number of private rooms will increase. The people in Erbil are not very concentrated on the dining rooms in the houses, because not all the houses have these rooms. The reason is that people get used to taking their meals either in the kitchen or in the family lounge as an alternative. Hence, people with more income could have this type of room in their houses. The study concluded that the family lounge rooms are the most important part of their houses because they spend more time as a family in this part of the house. The study comes out with a result that the lifestyle is significantly affected by the income of the families. This was obvious through the change in the lifestyle of each group of selected families in Erbil based on their income.

\section{References}

Al-Hamoud, M., Al-Oun, S., Abed, A. (2010). Socio-spatial Measures of Bedouin Homes as an Effect of Lifestyle in Northeastern Badia of Jordan - Constancy and Change. Amman: Jordan: BRDC.

Amin, R., and Muhy Al-din, S.S. (2018). Evaluation of the Sustainable Aspects in Housing Sector to Overcome Housing Stress in Northern Iraq. Journal of Contemporary Urban Affairs (JCUA), 3(1). DOI: 10.25034/ijcua.2018.4684.

Bolt, H.M. (2002). Occupational versus environmental and lifestyle exposures of children and adolescents in the European Union. Toxicol Lett, 127.121-126. 


\section{QALAAI ZANISTSCIENTIFIC JOURNAL \\ A Scientific Quarterly Refereed Journal Issued by Lebanese French University - Erbil, Kurdistan, Iraq \\ Vol. (5), No (2), Spring 2020 \\ ISSN 2518-6566 (Online) - ISSN 2518-6558 (Print)}

Coles, J., and House, N. (2007). The Fundamentals of Interior Architecture. Switzerland: AVA Publishing SA.

Cockerham, W.C. (2002). Health lifestyles in Russia. Soc Sci Med, 51.1313 - 1324.

Connolly, J., Prothero, A. (2003). Sustainable consumption: consumption, consumers and the commodity discourse. Consumpt Markets Cult 6. 275- 291.

Fadhil, A. M. (2011). Drought Mapping Using Geo-information Technology for Some Sites in the Iraqi Kurdistan Region. International Journal of Digital Earth, 4(3), 239-257.

Huang, Y. (2011). How human-computer interface redefines original lifestyle in architecture?. Advanced Materials Research, 250, 1088-1097. Doi:10.4028/www.scientific.net/AMR.250-253.1088

IOM (World Migration Report), (2018). DEMOGRAPHIC SURVEY: KURDISTAN REGION OF IRAQ. UN Migration- Iraq Mission. Retrieved from, http://www.iomiraq.net/article/0/statistics-office-iom-and-unfpa-launch-demographicsurvey-kurdistan-region-iraq

Kahle, L. R., and Close, A. G. (2011). Consumer Behavior Knowledge for Effective Sports and Event Marketing. New York, USA: Routledge.

Khalid, N. J. (2014). Urban Heat Island in Erbil City. Master Thesis. Lund University, Lund. Sweden: Lund University.

Lang, J. (1987). Creating Architectural Theory: The Role of the Behavioral Sciences in

Environmental Design. New York, USA: Van Nostrand Reinhold.

Lee, S., Alzoubi, H., \& Kim, S. (2017). The Effect of Interior Design Elements and Lighting Layouts on Prospective Occupants' Perceptions of Amenity and Efficiency in Living Rooms. Sustainability, 9(7), 1119. Doi: 10.3390/su9071119 


\section{QALAAI ZANISTSCIENTIFIC JOURNAL \\ A Scientific Quarterly Refereed Journal Issued by Lebanese French University - Erbil, Kurdistan, Iraq \\ Vol. (5), No (2), Spring 2020 \\ ISSN 2518-6566 (Online) - ISSN 2518-6558 (Print)}

Lee, S., \& Wohn, K. (2016). Occupants' Perceptions of Amenity and Efficiency for Verification of Spatial Design Adequacy. International Journal of Environmental Research and Public Health, 13(1), 128. Doi: 10.3390/ijerph13010128

Lufkin, S., Thomas, M., Kaufmann, V., and Rey, E. (2018). Linking spatial characteristics to residential lifestyles. Journal of Urban Research. Retrieved from, https://journals.openedition.org/articulo/3498

Mahmoud, H.T. (2014). Interior Architectural Elements that Affect Human Psychology and Behavior. International Journal on: The Academic Research Community Publication. DOI: 10.21625/archive.v1i1.112

Meho, L. I. (1997). The Kurds and Kurdistan: a selective and annotated bibliography. USA: Greenwood Press.

Pulkkinen, L., and Kokko, K. (2000). Identity development in adulthood: A longitudinal study. J Research in Personality, 34. 445 - 470.

Rapoport, A. (1969). House Form and Culture. Englewood Cliffs, N.J., USA: Printice-Hall.

Rashdan, W. (2016). The impact of innovative smart design solutions on achieving sustainable interior design. WIT Transactions on Ecology and The Environment, 204. Doi: $10.2495 /$ SC160521

Richardson, M. (1989). The Artifacts as Abbreviated Act: a Social Interpretation of Material Culture. In 'The Meaning of Things: Material Culture and Symbolic Expression'. I. Hodder et al., (Eds.). London, UK: Unwin Hyman.

Saeed, M. A. (2003). Estimation of Reference Evapotranspiration from Climatic Data in Kurdistan Region-Iraq. College of Basic Education-Salahaddin University, Erbil. Iraq: Salahaddin University.

Sidawi, B. (2008). Incorporating Lifestyle in the Design of Affordable Housing in Saudi Arabia Kingdom. Emirates Journal for Engineering Research, 13 (2), 67-72. 


\section{QALAAI ZANISTSCIENTIFIC JOURNAL}

A Scientific Quarterly Refereed Journal Issued by Lebanese French University - Erbil, Kurdistan, Iraq

Vol. (5), No (2), Spring 2020

ISSN 2518-6566 (Online) - ISSN 2518-6558 (Print)

Stoll-Kleemann, S., O'Riordan, T., Jaeger, C.C. (2001). The psychology of denial concerning climate mitigation measures: evidence from Swiss focus groups. Global Environ Change, $11.107-117$

Tognoli, J. (1987). Residential Environments. In I. Altman and D. Stokols (Eds.). Handbook of

Environmental Psychology. Vol.1, pp655-690. New York, USA: Wiley Sons.

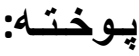

ئامانجى ئهم تويّزّينهوهيه بريتيه له دوزينهوهى شيّوازهكانى رَيان له شارى ههوليّر ئه شه لهبهرياوكرتنى كاريكهى تهلارسازى لهسهر يه كهانى نيشتهجيِبون. تويّزّينه كه به شيّوهيه كى نزيك ليّكولينهوه له سهر •" يهكه نيشتهجيّبون له هوليّر كراوه ئهمه وهكو نمونه بو ئهوه لسنورى ئهم تويّزّينهوهيه ديارى بكريّت. يهكهانى نيشتهجيّبون دابه كراون لهسهر لى ئاست (نزم، ناوهند، بهرز) به كويّرهى داهاتى خانهوادهكان. رايرسيه كئامادهراوه بو كهيشتن به ئهنجامه كانى تويّزّينهوهكه. فاكتهرهكانى ليّوربونهوه

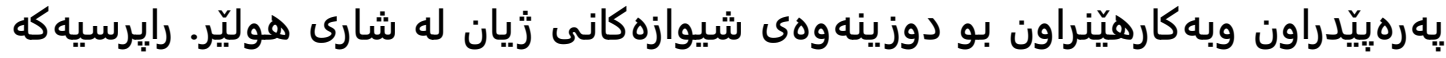
يَهرهيِيدراوه بو دوزينهوهى شيّوازهكانى زيّان له ريّكهى يرسياركردن له خانهوادهكان

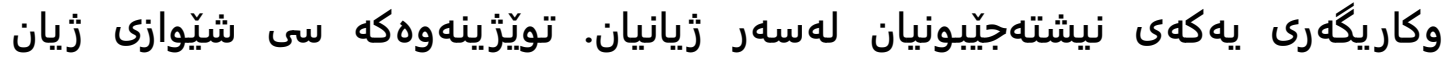
دياريدهكات له شارى ههوليّر له سهر ئاستى داهات وكاريكهرى لهسهر يهكه نيشتهجيّبون ئهمه به بئه گهى ههبونى زورى خواردن وكهلويهلى خواردن وههروهها شيوازى زيانى خيزانه كه به كويّرهى يهيوهنديه كانى ئهندامهكانى خيّزان له ناو خودى خيزّانه كه وههروه ها لهناو كومهلكاى دهوروبهرى. تويّزّينهوهكه ئهوه دهردهخات كه يهيوهنديه كه به هيّز ههيه لهنيوان ئهندمه كانى خيّزان وكومهلكاى دهوربهرى وههروهها ئهوهش دهردهخات كه كاريكهرى زور ههيه لهسهر شيّوازى زيّان به گُويرهى داهاتى خيّزان

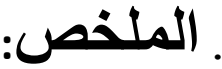

تهدف الدراسة إلى تحديد نمط المعيشة الحالي (نمط الحياة) في مدينة أربيل وانعكاسه على العمارة ومكونات الوحدة السكنية. تم الاقتراب من منهجية دراسة الحالة ، وتم اختيار 30 مبنى سكني لتحليلها في أربيل كحد للدراسة. تم تقسيم المباني إلى ثلاث 
فئات (منخفضة ومتوسطة وعالية) حسب دخل الأسرة في منطقة الدراسة. تم تنفيذ طرق

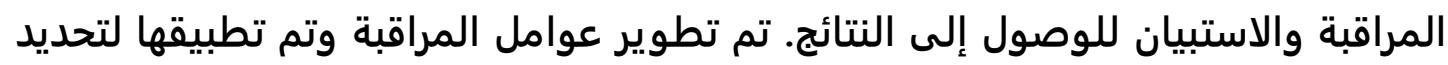

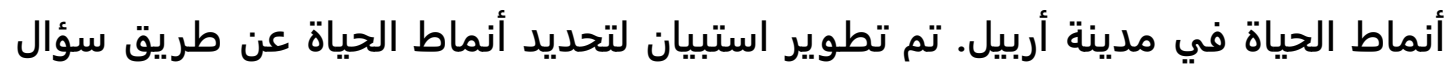

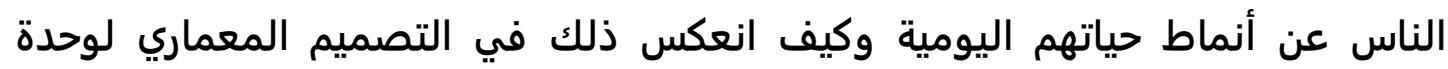

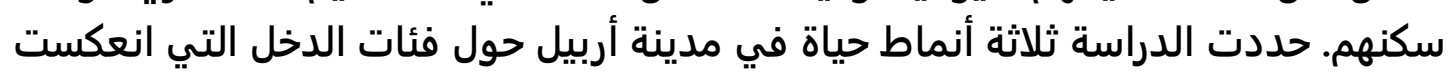

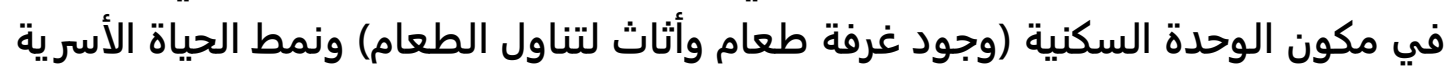

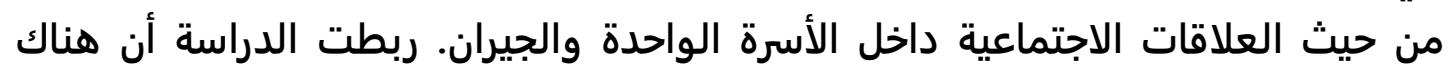

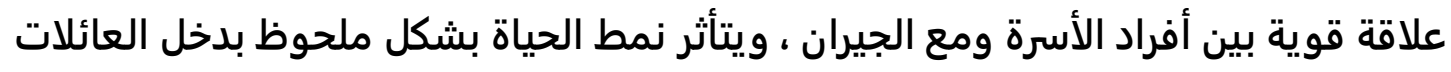

